\title{
PELATIHAN KADER KESEHATAN MENGENAI PENGELOLAAN KESEHATANLANSIA DI MASA PANDEMI COVID 19 SEBAGAI UPAYA MENINGKATKAN KESEHATAN LANSIA
}

\author{
Nanik Dwi Astutik ${ }^{1}$, Ellia Ariesti ${ }^{2}$ \\ ${ }^{1}$ Prodi S1-Keperawatan, STIKes Panti Waluya Malang \\ ${ }^{2}$ Prodi D-III-Keperawatan, STIKes Panti Waluya Malang \\ Korespondensi penulis: Alamat: Jalan Yulius Usma No. 62, Malang 65117, telepon: \\ 0341 369003, email: nanikd79@gmail.com
}

\begin{abstract}
ABSTRAK
Meningkatnya jumlah lansia secara kuantitas harus mendapatkan perhatian yang besar agar lansia mampu melewati masa tuanya dengan sukses, dan mampu mempertahankan kesehatannya di tengah pandemi Covid 19. Puskesmas Tajinan telah memiliki program pelayanan terpadu (posyandu) lansia yang rutin diadakan tiap bulan. Akan tetapi kegiatan tersebut untuk sementara terhenti karena terkendala tidak boleh keluar rumah di masa Covid 19. Lansia termasuk kelompok yang rentan tertular virus Corona karena di usia tersebut terjadi penurunan produksi hormon dan fungsi organ-organ tubuh. Menurut laporan yang dikeluarkan organisasi kesehatan dunia (WHO), angka kematian paling banyak akibat Covid 19 adalah lansia di atas umur 80 tahun. Di masa Covid 19 ini para kader tidak dapat mendampingi lansia secara langsung padahal lansia perlu diberi pengetahuan dan pendampingan agar siap menghadapi Covid 19. Adanya penurunan fungsi kognitif dapat mempersulit lansia memahami alasan di balik berbagai tindakan pencegahan, seperti mengapa tidak boleh keluar rumah, mengapa harus memakai masker dan sebagainya. Oleh karena itu,pendekatan dan cara berkomunikasi dengan lansia perlu sedikit penyesuaian. Berdasarkan potensi kader posyandu lansia dan hasil assesmen yang telah diuraikan tersebut maka perlu diberikan pengetahuan dan pemahaman mengenai pengelolaan kesehatan lansia untuk meningkatkan pemahaman kader kesehatan sebagai upaya peningkatan kesehatan lansia dimasa pandemi Covid 19.
\end{abstract}

\section{Kata Kunci: Kader kesehatan, Pengelolaan Kesehatan Lansia, Pandemi Covid 19}

\begin{abstract}
The increasing number of elderly in quantity must get a great attention so that the elderly can pass through their old age successfully, and be able to maintain their health in the midst of the covid 19 pandemic.Tajinan Health Center already has an integrated service program (posyandu) for the elderly that is routinely held every month. However, the activity was temporarily suspended due to constraints on not being allowed to leave the house during Covid 19. Elderly people are among the vulnerable to contracting corona virus because at that age there is a decrease in hormone production and function of the body's organs. According to a report issued by the World Health Organization (WHO), the highest death rate due to COVID-19 is the elderly over the age of 80. During the covid 19 period, cadres cannot accompany the elderly directly even though the elderly need to be given knowledge and assistance to be ready to face COVID 19.. The presence of cognitive impairment can make it difficult for the elderly to understand the reasons behind various precautions, such as why they should not leave the house, why they should wear masks, and so on. Therefore, the approach and way of communicating with the elderly needs a little adjustment. Based on the potential of elderly posyandu cadres and the assessment results that have been described, it is necessary to provide knowledge and understanding on elderly health management to improve the understanding of health cadres as an effort to improve the health of the elderly during the covid 19 pandemic.
\end{abstract}

\section{Keywords: Health Cadres, Elderly Health Management, Covid 19 Pandemic}


Meningkatnya jumlah lansia secara kuantitas harus mendapatkan perhatian yang besar agar lansia mampu melewati masa tuanya dengan sukses, dan mampu mempertahankan kesehatannya di tengah pandemi covid 19. Puskesmas Tajinan telah memiliki program pelayanan terpadu (posyandu) lansia yang rutin diadakan tiap bulan. Akan tetapi kegiatan tersebut untuk sementara terhenti karena terkendala tidak boleh keluar rumah di masa Covid 19.

Lansia termasuk kelompok yang rentan tertular virus Corona karena di usia tersebut terjadi penurunan produksi hormon dan fungsi organ-organ tubuh. Bahkan lansia yang telah memiliki penyakit kronis seperti hipertensi, diabetes dan kanker lebih rentan tertular karena kekebalan tubuh yang terus menurun.

Menurut laporan yang dikeluarkan organisasi kesehatan dunia (WHO), angka kematian paling banyak akibat Covid19 adalah lansia di atas umur 80 tahun. Sejauh ini lansia dan orang-orang yang sudah memiliki keadaan medis sebelumnya (seperti tekanan darah tinggi, penyakit jantung, penyakit paruparu, kanker atau diabetes) terindikasi mengalami sakit yang lebih parah.

Disisi lain lansia juga merasa kehilangan kehidupan normal akibat perubahan yang mendadak. Mereka tidak bisa lagi bertatap muka dengan teman-teman, yang mungkin selama ini menjadi hiburan mengisi waktu dan motivasi. Di masa pandemi covid 19 ini para kader tidak dapat mendampingi lansia secara langsung padahal lansia perlu diberi pengetahuan dan pendampingan agar siap menghadapi Covid 19.

Lansia sulit untuk bisa memahami dan mencerna beberapa himbauan yang diberikan pemerintah terkait upaya menjaga diri agar tidak terpapar virus
Covid 19. Adanya penurunan fungsi kognitif dapat mempersulit lansia memahami alasan di balik berbagai tindakan pencegahan, seperti mengapa tidak boleh keluar rumah, mengapa harus memakai masker, dan sebagainya. Oleh karena itu, pendekatan dan cara berkomunikasi dengan lansia perlu sedikit penyesuaian.

Masyarakat yang berada di Dusun Tambakrejo khususnya lansia masih belum memeiliki kesadaran kesehatan baik kesehatan secara fisik maupun mental. Secara fisik sebagian besar lansia menderita penyakit hypertensi sedangkan secara mental/psikologis banyak lansia yang mengeluh sering mengalami kecemasan dan sulit untuk tidur apalagi di masa pandemi covid 19. Hal ini sesuai dengan yang disampaikan salah satu kader posyandu lansia, bahwa banyak lansia yang kurang memiliki pengetahuan dan pemahaman tentang pengelolaan kesehatan dalam upaya menjaga diri agar tidak terpapar virus Covid 19. Berdasarkan potensi kader posyandu lansia dan hasil assesmen yang telah diuraikan tersebut maka perlu diberikan pengetahuan dan pemahaman mengenai pengelolaan kesehatan lansia untuk meningkatkan pemahaman kader kesehatan sebagai upaya peningkatan kesehatan lansia dimasa pandemi covid 19.

Hal ini bisa menimbulkan berbagai masalah dalam upaya pencegahan covid 19 apa bila tidak segera ditangani. Sehingga lanjut usia perlu mendapatkan perhatian yang serius dari semua sektor untuk upaya peningkatan kesehatan fisik dan mental agar tetap sehat dan bahagia. Salah satu bentuk perhatian yang serius terhadap lanjut usia adalah terlaksananya pelayanan pada lanjut usia melalui kader posyandu lansia.

Namun tidak dapat dipungkiri, kendala atau hambatan juga banyak dialami: 
kurangnya pengetahuan dan pemahaman kader kesehatan / posyandu lansia mengenai materi-materi yang harus disampaikan pada lansia dan keluarga lansia terkait pengelolaan kesehatan lansia di masa pandemi covid 19 dan terbatasnya media promosi untuk melakukan penyuluhan dalam upaya penggerakan dan pemberdayaan keluarga untuk pencegahan COVID-19. Atas dasar permasalahan sebagaimana diuraikan di atas, maka prioritas kegiatan yang perlu segera ditangani yaitu pemberian pengetahuan dan pemahaman serta media promosi yang akan digunakan untuk meningkatkan pemahaman kader posyandu lansia dalam pengelolaan kesehatan lansia di masa pandemi covid 19.

\section{METODE}

Kegiatan Program Kemitraan Masyarakat di Kabupaten Malang dilaksanakan dengan pendekatan peningkatan pemahaman dari para kader kesehatan mengenai pengelolaan kesehatan lansia di masa pandemi covid 19 sebagai upaya meningkatkan kesehatan lansia. Pendekatan tersebut dilakukan melalui kegiatan pendidikan kesehatan edukasi mengenai pengelolaan kesehatan lansia di masa pandemi covid 19 sebagai upaya meningkatkan kesehatan lansia yang meliputi: Perilaku hidup sehat dan bersih guna pencegahan penularan covid 19, Pemantauan kesehatan lansia, Pentingnya kesehatan mental bagi lansia, Aktivitas lansia untuk mengurangi depresi di masa covid 19.

\section{ALAT DAN BAHAN}

Alat dan bahan yang digunakan selama proses kegiatan program kemitraan masyarakat (PKM) ini ialah berupa media. Media yang akan digunakan dalam kegiatan PKM ini ialah ppt dan modul pelatihan. Powerpoint (ppt) dan modul pelatihan yang digunakan dalam kegiatan PKM ini memiliki konten mengenai perilaku hidup sehat dan bersih guna pencegahan penularan covid 19, pemantauan kesehatan lansia, pentingnya kesehatan mental bagi lansia dan aktivitas lansia untuk mengurangi depresi di masa covid 19. Pada akhir kegiatan PPT dan modul pelatihan video dibagikan pada peserta pelatihan dan kader kesehatan yang mengikuti pelatihan untuk dapat disosialisasikan kepada seluruh masyarakat dan warga sekitar khususnya pada warga lansia.

Metode pelaksanaan kegiatan dibagi menjadi tiga tahap, yaitu persiapan, pelaksanaan, dan evaluasi. Tahapan persiapan meliputi persiapan media yang akan digunakan dalam kegiatan PKM ini. Persiapan media dilakukan dengan pembuatan ppt dan modul pelatihan. Selain itu, pada tahap persiapan dilakukan dengan menganalisis fenomena yang sesuai dengan kondisi saat ini, melakukan pendekatan kepada tokoh masyarakat dan petugas kesehatan, melakukan pertemuan dengan kader kesehatan dan secara bersama-sama dengan mitra membuat prioritas penenganan masalah dan menentukan jenis kegiatan. Tahap pelaksanaan meliputi kegiatan penyuluhan kesehatan dan pelatihan kepada kader kesehatan yang meliputi: pengelolaan kesehatan fisik dan mental pada lansia di masa pandemi covid 19 dengan menggunakan media penyuluhan yang sudah dibuat. Tahap evaluasi pada peserta kegiatan dilakukan melalui observasi, pre-test dan post-test tulis. Evaluasi dilakukan untuk mengukur pemahaman terkait materi di ppt dan modul yang telah dibagikan. Program pelatihan ini dilakukan dengan tahapantahapan tersebut yang dapat berdampak pada keaktifan kader kesehatan dan pserta pelatihan. 
Hasil analisis fenomena yang sesuai dengan kondisi saat ini telah dilaksanakan pada tahap persiapan. Hasil tersebut dipaparkan dalam tabel 1 .

\section{Tabel 1. Permasalahan dan kegiatan PKM sebagai solusi permasalahan}

\begin{tabular}{|c|c|c|c|}
\hline No. & Permasalahan & Kegiatan Solusi Permasalahan & $\begin{array}{l}\text { Partisipasi Mitra } \\
\text { Dalam Kegiatan }\end{array}$ \\
\hline 1 & $\begin{array}{l}\text { Belum berkembangnya } \\
\text { kemandirian mitra untuk } \\
\text { mengenali pandemi covid } 19\end{array}$ & $\begin{array}{l}\text { Pendidikan kesehatan berupa } \\
\text { ppt dan modul tentang covid } 19 \\
\text { edukasi pada Kader Kesehatan } \\
\text { dan perkumpulan Dasa Wisma }\end{array}$ & $\begin{array}{l}\text { Berperan aktif sebagai } \\
\text { peserta. }\end{array}$ \\
\hline 2 & $\begin{array}{l}\text { Belum berkembangnya } \\
\text { kemandirian mitra untuk } \\
\text { mengenali pengelolaan } \\
\text { kesehastan fisik lansia di masa } \\
\text { pandemi covid } 19\end{array}$ & $\begin{array}{l}\text { Pendidikan kesehatan dan } \\
\text { pelatihan pada kader mengenai } \\
\text { pengelolaan kesehatan fisik } \\
\text { lansia di masa pandemi covid } \\
\text { 19. }\end{array}$ & $\begin{array}{l}\text { Berperan aktif sebagai } \\
\text { peserta }\end{array}$ \\
\hline 3 & $\begin{array}{l}\text { Belum berkembangnya } \\
\text { kemandirian mitra untuk } \\
\text { mengenali pengelolaan } \\
\text { kesehastan mental lansia di masa } \\
\text { pandemi covid } 19\end{array}$ & $\begin{array}{l}\text { Pendidikan kesehatan dan } \\
\text { pelatihan pada kader mengenai } \\
\text { pengelolaan kesehatan fisik } \\
\text { lansia di masa pandemi covid } \\
\text { 19. }\end{array}$ & $\begin{array}{l}\text { Berperan aktif sebagai } \\
\text { peserta }\end{array}$ \\
\hline 4 & $\begin{array}{l}\text { Belum berkembangnya } \\
\text { kepercayaan diri masyarakat } \\
\text { untuk berperan aktif dalam } \\
\text { program peningkatan kesehatan } \\
\text { berbasis masyarakat di masa } \\
\text { pandemi covid } 19 .\end{array}$ & $\begin{array}{l}\text { Pendidikan kesehatan dan } \\
\text { pelatihan pada kader mengenai } \\
\text { mengenai upaya peningkatan } \\
\text { kesehatan lansia berbasis } \\
\text { masyarakat di masa pandemi } \\
\text { covid } 19 \text {. }\end{array}$ & $\begin{array}{l}\text { Berperan aktif sebagai } \\
\text { peserta }\end{array}$ \\
\hline
\end{tabular}

Hasil kegiatan dari PKM yang berjudul "Pelatihan Kader Kesehatan Mengenai Pengelolaan Kesehatan Lansia Di Masa Pandemi Covid 19 Sebagai Upaya Meningkatkan
Kesehatan Lansia " dipaparkan dalam tabel 2:

\section{Tabel 2. Hasil Kegiatan PKM}

\begin{tabular}{cclcc}
\hline No & Waktu & \multicolumn{1}{c}{ Kegiatan } & Peserta \\
\hline 1 & 5 Agustus 2020 & $\begin{array}{l}\text { Pembukaan, } \\
\text { kegiatan PKM dan pelaksanaan pre-test }\end{array}$ & 25 Kader
\end{tabular}

$2 \quad 10$ Agustus 2020

3

15 Agustus 2020
Penyuluhan kader menggunakan ppt :

1. Edukasi mengenai konsep menua

2. Edukasi mengenai pandemi covid 19

Penyuluhan dan pelatihan kader menggunakan ppt \& simulasi :

1. Pengelolaan kesehatan secara umum

2. Pengelolaan kesehatan di masa pandemi covid 19.

3. Pengelolaan kesehatan secara fisik pada lansia
25 Kader

25 Kader 
4. Pengelolaan kesehatan secara fisik pada lansia di masa pandemi covid 19

Penyuluhan dan pelatihan kader menggunakan ppt \& simulasi :

1. Pengelolaan kesehatan mental di masa pandemi covid 19.

2. Pengelolaan kesehatan mental pada lansia di masa pandemi covid 19.

Penutupan, tanya jawab, evaluasi

25 Kader kegiatan dan pelaksanaan post-test

Program Kemitraan Masyarakat pada pertemuan pertama setelah sebelumnya melakukan survey lokasi dan kondisi kesehatan masyarakat selanjutnya ialah koordinasi dengan kepala desa, kepala dusun, ketua RW \& RT, tokoh masyarakat serta kader kesehatan. Selanjutnya persiapan media edukasi dan modul pelatihan. perkenalan dengan peserta kegiatan PKM dan dilanjutkan dengan kegiatan pre-test. Pada pertemuan pertama, peserta yang hadir ialah 25 orang kader kesehatan. Sebelum memulai kegiatan pre-test, terlebih dahulu pemateri melakukan perkenalan dan pengarahan terkait dengan kegiatan PKM. Kegiatan pengarahan yang dilakukan dengan menjelaskan tentang rencana kegiatan yang akan dilakukan selama proses kegiatan PKM dan tujuan dilakukan PKM. Setelah kegiatan perkenalan dan pengarahan, pemateri memberikan pretest secara tertulis kepada peserta kegiatan. Hasil evaluasi pre-test dari 25 peserta yang ada didapatkan rata-rata nilai sebesar 52,3 dengan jumlah soal pre-test sebanyak 10 soal. Peserta yang hadir pada kegiatan PKM tampak aktif menanggapi selama kegiatan awal PKM dilaksanakan.

Program Kemitraan Masyarakat pada pertemuan kedua ialah pemberian penyuluhan dan pelatihan mengenai proses sharing video edukasi mengenai konsep menua, konsep succesful aging dan informasi pandemiCovid-19. Pada pertemuan kedua ini, penyuluhan dan pelatihan menggunakan modul dan ppt yang dibagikan pada kader. Tujuan pelatihan pada pertemuan kedua ini adalah memberikan informasi dan pelatihan tentang konsep menua, konsep succesful aging dan peran prose menua terhadap succesful aging. Evaluasi dari hasil pelatihan adalah kader kesehatan mengerti tentang konsep menua dan penularan covid 19 terutama pada lansia.

Program Kemitraan Masyarakat pada pertemuan ketiga ialah penyuluhan dan pelatihan kepada kader kesehatan mengenai: pengelolaan kesehatan secara fisik pada lansia di masa pandemi covid 19. Tujuan pelatihan pada pertemuan ketiga ini adalah memberikan informasi dan pelatihan tentang pengelolaan kesehatan secara fisik pada lansia di masa pandemi covid 19. Evaluasi hasil pelatihan adalah kader kesehatan mengerti dan memahami tentang pengelolaan kesehatan secara fisik pada lansia di masa pandemi covid 19 dan bagaimana cara memberikan edukasi pada lansia.

Program Kemitraan Masyarakat pada pertemuan keempat ialah penyuluhan dan kepada kader kesehatan mengenai: pengelolaan kesehatan mental pada lansia di masa pandemi covid19. Tujuan pelatihan pada pertemuan keempat ini adalah Memberikan pemahaman dan ketrampilan kepada kader kesehatan mengenai pengelolaan kesehatan mental pada ansia di masa pandemi covid 19. Evaluasi hasil pelatihan adalah kader 
kesehatan mengerti dan memahami tentang pengelolaan kesehatan mental pada lansia di masa pandemi covid 19.

Program Kemitraan Masyarakat pada pertemuan kelima ialah penutupan kegiatan PKM dan evaluasi kegiatan PKM. Evaluasi dilakukan dengan posttest yang diberikan pada seluruh peserta kegiatan PKM. Sebelum memulai posttest, fasilitator melakukan tanya jawab singkat terlebih dahulu untuk menyegarkan kembali pemahaman peserta mengenai materi penyuluhan. Post-test dilakukan secara tertulis. peserta yang memberikan umpan balik evaluasi dengan mengisi post-test ialah 25 peserta. Hasil evaluasi pre-test dari 25 peserta didapatkan rata-rata nilai sebesar 87,2 dengan jumlah soal pre-test sebanyak 10 soal.

Program Kemitraan Masyarakat (PKM) telah terlaksana dengan baik dan lancar, mengacu sesuai pada rencana kegiatan yang telah disusun. Evaluasi secara umum dari kegiatan PKM ini ialah terlaksananya kegiatan sesuai dengan jadwal yang telah ditetapkan, partisipasi juga aktif kehadiran peserta pada saat kegiatan berlangsung, serta terdistribusikan nya modul pelatihan mengenai pengelolaan kesehatan fisik dan mental pada lansia di masa pandemi covid 19 ke kader kesehatan. Secara umum acara berjalan dengan lancar sesuai dengan yang diharapkan. Keberhasilan suatu kegiatan sangat tergantung pada peran aktif dan partisipasi pesertanya. Peran aktif peserta dalam kegiatan IbM "Pelatihan dan Pemberdayaan Kader Kesehatan tentang "Pelatihan kader kesehatan mengenai pengelolaan kesehatan lansia di Desa Tambakasri wilayah kerja Puskesmas Tajinan Kabupaten Malang di masa pandemi covid 19 sebagai upaya meningkatkan kesehatan lansia dapat disimpulkan baik. Hal ini dapat dilihat dari antusias dan semangat dari peserta pelatihan baik kader kesehatan maupun masyarakat. Indikasi lain yang menguatkan kesimpulan ini adalah partisipasi aktif peserta ketika berdiskusi pada setiap sesi pelatihan serta ketepatan waktu sesuai dengan perencanaan.

Kegiatan pelatihan ini dapat berjalan dengan lancar dikarenakan adanya faktor yang mendukung, diantaranya antusiasme para peserta pelatihan yaitu antusiasme peserta yang dapat dibuktikan dengan banyaknya pertanyaan yang muncul ketika pelaksanaan pelatihan dan diskusi serta pelaksanaan kegiatan senam lansia yang diikuti oleh masyarakat yang sebagaian besar berusia lansia. Faktor lain yang mendukung terlaksananya kegiatan pelatihan ini adalah dukungan dari kepala desa, tokoh masyarakat, peran aktif puskesmas beserta Tim Pengabdi dari STIKes dan juga mahasiswa yang terlibat langsung pada kegiatan ini. Pada kegiatan ini tidak ditemukan faktor penghambat yang berarti, sehingga kegiatan dapat berjalan dengan lancar.

Kader kesehatan merupakan salah satu target utama dalam kegiatan PKM ini. Dengan adanya kegiatan ini, diharapkan kader dapat meningkatkan pemahaman nya terkait pengelolaan kesehatan fisik dan mental pada lansia pada masa pandemi Covid-19. Selain itu, diharapkan kader kesehatan dapat melakukan penyuluhan dan sosialisasi kepada masyarakat sekitar setelah mengikuti kegiatan PKM berupa pendidikan kesehatan mengenai pengelolaan kesehatan fisik dan mental pada lansia pada masa pandemi Covid19. Hal tersebut diharapkan dapat memaksimalkan fungsi kader kesehatan sebagaimana mestinya dan dapat membantu mengubah pola pikir dan pola hidup di masyarakat untuk meminimalkan terjadinya penularan covid 19 pada masyarakat khususnya lansia dalam menghadapi masa pandemi Covid-19.

Program kegiatan pengabdian kepada masyarakat ini diharapkan dapat membantu serta meningkatkan 
pemahaman masyarakat di era pandemi covid 19 ini terutama mengenai pengelolaan kesehatan fisik dan mental lansia di masa pandemi covid 19 melalui perwakilan tokoh masyarakat, kader kesehatan, dan tenaga kesehatan setempat untuk selanjutnya disosialisasikan kepada masyarakat khususnya para lansia.

\section{KESIMPULAN DAN SARAN}

Pelaksanaan Program

Pengabdian kepada Masyarakat ini dapat disimpulkan telah berjalan dengan baik, lancar, dan sukses. Hal ini dikarenakan pada saat pelaksanaan kegiatan IbM "Pelatihan dan Pemberdayaan Kader Kesehatan tentang "Pelatihan kader kesehatan mengenai pengelolaan kesehatan lansia di masa pandemi covid 19 sebagai upaya meningkatkan kesehatan lansia di Desa Tambakasri Wilayah Kerja Puskesmas Tajinan Kabupaten Malang yang telah dilaksanakan selama 6 bulan, yaitu bulan Februari sampai Agustus 2020 tingkat kehadiran peserta rata-rata $90 \%$, tersampaikannya semua materi oleh narasumber dan aktifnya peserta dalam diskusi yang dilakukan. Hal lain yang dapat dijadikan barometer kesuksesan acara ini adalah dari hasil evaluasi pada peserta saat dilaksanakan pelatihan. Peserta terlihat lebih antusias dalam memahami konsep lansia, pengelolaan kesehatan fisik dan mental pada lansia. Atas dasar ini pula dapat disimpulkan bahwa tujuan pelatihan yang ingin meningkatkan pengetahuan dan pemahaman kader kesehatan mengenai pengelolaan kesehatan lansia di masa pandemi covid 19 sebagai upaya meningkatkan kesehatan lansia di Desa Tambakasri kabupaten Malang dapat tercapai.

Sebaiknya meskipun pelatihan selesai dilakukan diharapkan agar kader kesehatan, tokoh-tokoh masyarakat dan pihak puskesmas tetap berkoordinasi dan tetap memantau pelaksanaan protokol kesehatan dan pengelolaan kesehatan lansia di masa pandemi covid 19 sebagai upaya meningkatkan kesehatan lansia di Desa Tambakasri wilayah kerja Puskesmas Tajinan Kabupaten Malang agar lansia bisa tetap sehat di masa pandemi covid 19 sehingga derajat kesehatan masyarakat juga meningkat.

DAFTAR PUSTAKA

Amalia, A. (2013) Kesepian dan Isolasi yang dialami Lanjut Usia: Tinjauan dari Perspektif Sosiologis. Pusat Penelitian dan Pengembangan Kesejahteraan Sosial Kemensos RI, Jurnal Informasi Vol. 18, No. 02, Tahun 2013.

Azizah, Lilik. M.(2011) . Keprawatan Lanjut Usia. Edisi I Yogyakarta: Graha Ilmu

Bandura, Albert. (2001). Self Efficacy. New York: W.H. Freeman and Company.

Darmojo dan Boedhi, R. 2009. Buku Ajar Geriatri Ilmu Kesehatan Usia Lanjut. Jakarta : FKUI

Dorris.(2003). Successful and active aging. The Journal on Active Aging.2 (6), November - Desember.

.Effendi, F \& Makhfudli. (2009). Keperawatan Kesehatan Komunitas: teori dan Praktek Dalam Keperawatan. Jakarta: Salemba Medika.

Maryam, Siti R. et al. (2008). Mengenal Usia Lanjut dan Perawatannya. Jakarta: Salemba Humanika.

Mubarak. 2009. Ilmu Kesehatan Masyarakat: Teori Dan Aplikasi. Jakarta: Salemba Medika.

Padila. 2013. Buku Ajar Keperawatan Gerontik. Yogyakarta: Nuha Medika.

Rahmawati F. \& Saldiyah S. (2016). Makna Sukses Di Masa Lanjut. 
Jurnal Ilmiah Psikologi, Juni 2016, Vol.3, No.1.

Sadock B. J., Sadock V. A. 2010. Kaplan \& Sadock's Concise Text Book Of Clinical Psychiatry, 2Nd ed. Diterjemahkan Oleh Profitasari dan TM Nisa dengan Judul Kaplan \& Sadock Buku Ajar Psikiatri, Ed 2. Jakarta : EGC
Santrock, John W.2003. Life Span Development Perkembangan edisi keenam. Jakarta: Erlangga

Sarafino, E.P. (2002). Health psychology biopsychological interaction. USA: John Wiley \& Sons. 